\title{
Effects of Electrical Conductivity, pH, and Foliar Application of Calcium Chloride on Yield and Tipburn of Lactuca sativa Grown Using the Nutrient-Film Technique
}

\author{
Uttara Samarakoon and Jack Palmer \\ The Ohio State University Agricultural Technical Institute, 1328 Dover \\ Road, Wooster, $\mathrm{OH} 44691$
}

\author{
Peter Ling \\ Department of Food, Agricultural and Biological Engineering, 1680 \\ Madison Avenue, Ohio State University, Wooster, $\mathrm{OH}$
}

\section{James Altland}

U.S. Department of Agriculture, Agricultural Research Service, 1680 Madison Avenue, Wooster, $\mathrm{OH}$

Additional index words. hydroponics, lettuce, nutrient solution, nutrient uptake

\begin{abstract}
Yield reduction resulting from high temperatures and tipburn are common issues during the summer for hydroponically grown lettuce using the nutrient-film technique (NFT). We investigated the yield and degree of tipburn of lettuce 'Red Butter', 'Green Butter', and 'Red Oakleaf' of the Salanova ${ }^{\circledR}$ series under different-solution electrical conductivity (EC) and $\mathrm{pH}$ levels. We also quantified the effect of foliar spray application of calcium chloride $\left(\mathrm{CaCl}_{2}\right)$ on the yield and degree of tipburn using the lettuce cultivar Green Butter. For the EC experiment, the plants were grown at four EC levels $\left(1.4,1.6,1.8\right.$, or $\left.2.0 \mathrm{mS} \cdot \mathrm{cm}^{-1}\right)$ and a constant $\mathrm{pH}$ of 5.8. For the $\mathrm{pH}$ experiment, the plants were grown at and four $\mathrm{pH}$ levels $(5.8,6.0,6.2$, or 6.4) and a constant EC of 1.8 $\mathrm{mS} \cdot \mathrm{cm}^{-1}$. For the foliar spray experiment, $\mathrm{CaCl}_{2}$ was applied 1 week after transplanting into NFT channels at three different concentrations: $0,200,400$, or $800 \mathrm{mg} \cdot \mathrm{L}$ calcium (Ca). During the EC trial, the maximum yields were observed at or more than 1.8 $\mathrm{mS} \cdot \mathrm{cm}^{-1}$ for 'Green Butter' (263 $\left.\pm 14 \mathrm{~g} / \mathrm{head}\right)$ and 'Red Butter' $(202 \pm 8 \mathrm{~g})$, and more than $1.6 \mathrm{mS} \cdot \mathrm{cm}^{-1}$ for 'Red Oakleaf' $(183 \pm 6 \mathrm{~g})$. The yield of 'Green Butter' was $75 \mathrm{~g}$ less at 1.4 $\mathrm{mS} \cdot \mathrm{cm}^{-1}$ compared with $1.8 \mathrm{mS} \cdot \mathrm{cm}^{-1}$. Tipburn symptoms were less at $1.4 \mathrm{mS} \cdot \mathrm{cm}^{-1}$ for 'Green Butter' whereas other cultivars were not highly susceptible. In pH trials, the maximum yield for all cultivars was found at $\mathrm{pH} 6.0$ and 6.2. There were no differences in tipburn symptoms among all pH levels. The foliar spray treatment, twice a week at 400 or $800 \mathrm{mg} \cdot \mathrm{L}^{-1} \mathrm{Ca}$, provided improved tipburn control, as the tipburn symptoms were minimal and the impact on yield was minor compared with reducing EC. This series of experiments found evidence in proper $\mathrm{EC}$ and $\mathrm{pH}$ management for optimum yield and tipburn control in NFT lettuce grown in summer conditions.
\end{abstract}

Hydroponic greenhouse vegetable production is growing rapidly (Walters et al., 2020) with the increased interest in consumption of fresh, high-quality, local food yearround. Among differe nt hydroponic systems,

Received for publication 10 Apr. 2020. Accepted for publication 2 June 2020.

Published online 1 July 2020.

Technical support by Robert Hanson, Mike Klingman, Nathan Donley, and Suranga Basnagala of The Ohio State University is greatly acknowledged. We thank Douglas Sturtz (U.S. Department of Agriculture, Agricultural Research Service) for the nutrient analysis.

U.S. is the corresponding author. E-mail: samarakoon. 2@osu.edu.

This is an open access article distributed under the CC BY-NC-ND license (https://creativecommons. org/licenses/by-nc-nd/4.0/). maintain a desired EC level, the solution is adjusted periodically with the addition of fertilizer mixtures or dilution with water to maintain a constant EC level throughout the production period. Regardless of how much nutrients are added to the nutrient solution with proper EC management, $\mathrm{pH}$ level can affect macro- and micronutrient availability in the solution (De Rijck and Schrevens, 1999; Whipker et al., 2001). Solution pH can affect the solubility of some nutrients, which determines those nutrients available for plant uptake. Solution $\mathrm{pH}$ adjustments are conducted by adding acids or bases to the solution (Brechner et al., 2013). Solution EC and $\mathrm{pH}$ management are therefore key for successful nutrient management in a hydroponic system.

Climatic conditions such as temperature and humidity vary within a greenhouse during the growing seasons. Recommended day- and nighttime temperature set points for hydroponic lettuce in a greenhouse is $24^{\circ} \mathrm{C}$ day and $19^{\circ} \mathrm{C}$ night (Brechner et al., 2013). Based on our greenhouse temperature records and as reported by others (Watson et al., 2019), although the greenhouse air temperature is $24{ }^{\circ} \mathrm{C}$ or less from fall to spring, summer air temperature can reach $32{ }^{\circ} \mathrm{C}$ or more even with cooling systems running at full capacity. Therefore, the temperature difference between summer months and the rest of the production season (fall to spring) can be $20^{\circ} \mathrm{C}$ or more in northern U.S. greenhouses. Lower yields as well as physiological disorders such as tipburn often result from growing lettuce under such conditions (Frantz et al., 2004). Researchers have found the general trend of lowering EC to improve lettuce growth in a high-temperature environment because high transpiration rates can lead to a buildup of EC (Samarakoon et al., 2006). A reduction in EC levels from 1.8 to 1.0 $\mathrm{mS} \cdot \mathrm{cm}^{-1}$ (Abou-Hadid et al., 1995) and from 3.5 to $1.5 \mathrm{mS} \cdot \mathrm{cm}^{-1}$ (Serio et al., 2000) increased the fresh weight of lettuce in soilless culture.

Tipburn in lettuce is characterized by necrotic tips and margins on younger leaves, and can render crops unsalable. Tipburn is a common issue in hydroponically grown lettuce in NFT during the summer and under supplemental lighting during other seasons, as observed in commercial greenhouses and previous investigations (Samarakoon et al., 2019). Inner leaf tipburn is caused by an inadequate $\mathrm{Ca}$ supply to the younger leaf tissues (Barta and Tibbitts, 2000) because $\mathrm{Ca}$ cannot be mobilized from older tissues via phloem (White and Broadley, 2003). Climatic conditions that lead to faster growth rates such as high temperature and high light levels can induce this disorder. Although $\mathrm{Ca}$ is abundantly available in the nutrient solution, high humidity can reduce transpiration rates and affect water flow through the xylem, and therefore limit Ca uptake (Gilliham et al., 2011). Vertical airflow fans to circulate air and increase transpiration around the meristem can eliminate tipburn (Frantz et al., 
2004). The aim of our study was to use a nutrient management approach to alleviate tipburn.

Both EC and $\mathrm{pH}$ are important parameters in nutrient management. Based on previous investigations with lettuce (Samarakoon et al., 2019), yields were the greatest at EC levels of $1.8 \mathrm{mS} \cdot \mathrm{cm}^{-1}$, and yield reduction was associated with low $\left(0.8-1.2 \mathrm{mS} \cdot \mathrm{cm}^{-1}\right)$ and high $\left(2.4 \mathrm{mS} \cdot \mathrm{cm}^{-1}\right)$ EC levels. In 'Green Butter' lettuce, tipburn was associated with a greater yield resulting from an adequate fertilizer supply at an EC of 1.8 and $2.4 \mathrm{mS} \cdot \mathrm{cm}^{-1}$ (Samarakoon et al., 2019). The association of growth rate and tipburn occurrence in lettuce has been noted previously (Cox et al., 1976) and occurs because the Ca supply cannot compensate for the demand from the fastgrowing younger tissues in the plant (White and Broadley, 2003). An important tradeoff for using EC management as a method to control tipburn is that yields might also be reduced. In our study, therefore, we investigated an EC range closer to the recommended level. On the other hand, current recommendations are to use a pH of 5.6 to 6.0 (Brechner et al., 2013). The availability of $\mathrm{Ca}$ in a solution can vary with changes in $\mathrm{pH}$ (Whipker et al., 2001) and can influence the availability for uptake.

In addition to root-zone nutrient management, direct foliar nutrient application can be used to increase Ca content in the leaf tissues (Samarakoon et al., 2017). High humidity can reduce transpiration and limit Ca uptake from the root-zone nutrient solution even if a high concentration of $\mathrm{Ca}$ is available (Kuo et al., 1981). Foliar application might allow nutrients to be absorbed directly into leaves. $\mathrm{CaCl}_{2}$ has been used as a foliar spray to provide $\mathrm{Ca}$ as a nutrient source (Samarakoon et al., 2017) and disease control (Samarakoon et al., 2016; Starkey and Pedersen, 1997).

Hydroponic solution EC and $\mathrm{pH}$, as well as $\mathrm{Ca}$ uptake are all related and affect lettuce yield and tipburn occurrence. Therefore, we investigated the yield and degree of tipburn of three lettuce cultivars (Red Butter, Green Butter, and Red Oakleaf) of the Salanova ${ }^{\circledR}$ series in response to varying $\mathrm{EC}, \mathrm{pH}$, and foliar $\mathrm{Ca}$ application under summer greenhouse growing conditions.

\section{Materials and Methods}

Three experiments were carried out with lettuce grown in NFT systems to quantify the effects of $\mathrm{EC}, \mathrm{pH}$, and foliar application of $\mathrm{CaCl}_{2}$ on tipburn and yield. Expt. 1 examined the responses of growing lettuce under four different EC levels $(1.4,1.6,1.8$, or 2.0 $\mathrm{mS} \cdot \mathrm{cm}^{-1}$ ) at a $\mathrm{pH}$ of 5.8. Expt. 2 examined the responses of growing lettuce under four different $\mathrm{pH}$ levels $(5.8,6,6.2$, or 6.4$)$ at a constant EC of $1.8 \mathrm{mS} \cdot \mathrm{cm}^{-1}$. Expt. 3 examined the effect following foliar application of $\mathrm{CaCl}_{2}$ treatments $(\mathrm{Ca}$ at $0,200,400$, or 800 $\left.\mathrm{mg} \cdot \mathrm{L}^{-1}\right)$ twice a week of lettuce grown at an $\mathrm{EC}$ of $1.8 \mathrm{mS} \cdot \mathrm{cm}^{-1}$ and a $\mathrm{pH}$ of 5.8 .

Crop management. The experiments were conducted using the NFT systems established in a double polyethylene-plastic covered greenhouse at The Ohio State University, Wooster Campus, $\mathrm{OH}$ (lat. $40.78^{\circ} \mathrm{N}$, long. $\left.81.93^{\circ} \mathrm{W}\right)$. The greenhouse was covered with a black woven curtain with $40 \%$ shade during the experiments. Average light intensities were measured with a quantum sensor (SQ-110; Apogee Instruments, Logan, UT), and air temperature and relative humidity was measured with a combination probe (HMP50; Vaisala, Woburn, MA) and logged every $30 \mathrm{~min}$ via a data logger (CR3000; Campbell Scientific, Logan, UT). Macronutrients [nitrogen $(\mathrm{N})$, phosphorus $(\mathrm{P})$, potassium $(\mathrm{K}), \mathrm{Ca}$, magnesium $(\mathrm{Mg})$, and sulfur $(\mathrm{S})]$ and micronutrients [boron $(\mathrm{B})$, copper $(\mathrm{Cu})$, iron $(\mathrm{Fe})$, manganese $(\mathrm{Mn})$, molybdenum (Mo), and zinc ( $\mathrm{Zn})]$ were provided using a two-part fertilizer mixture (Crop King Lodi, $\mathrm{OH}$ ) consisting of Hydro-Gro Leafy Green [4.3N-9.3P-35K: $3.9 \mathrm{Mg}$ : $0.0002 \mathrm{~B}$, $0.0001 \mathrm{Cu}, 0.0021 \mathrm{Fe}$ (diethylene triamine pentaacetic acid chelate)], $0.0001 \mathrm{Mn}$, $0.00004 \mathrm{Mo}, 0.0002 \mathrm{Zn}$ ] and greenhousegrade calcium nitrate $15.5 \mathrm{~N}-19 \mathrm{Ca}$ (Crop King) was used for all experiments. Concentrated stock solutions were prepared according to manufacturer recommendations from the two fertilizers (Hydro-Gro Leafy Green $97.4 \mathrm{~g} \cdot \mathrm{L}^{-1}$ and calcium nitrate $\left.80 \mathrm{~g} \cdot \mathrm{L}^{-1}\right)$, and equal quantities of each solution were mixed with water in the NFT solution tank to achieve the desired EC level. Expt. 1 was conducted May to July; Expt. 2, from July to August. Three types of lettuce of the Salanova series ${ }^{\circledR}$ - 'Green Butter', 'Red Butter', and 'Red Oakleaf' (Johnny's Selected Seeds, Albion, ME) - were used for Expts. 1 and 2. For Expt. 3, conducted from July to August, 'Green Butter' of the Salanova series $^{\circledR}$ (Johnny's Selected Seeds), a cultivar susceptible to tipburn, was used.

Seedlings were germinated on 276-cell phenolic foam cubes (Horticubes ${ }^{\circledR}$; Smithers Oasis, Kent, $\mathrm{OH}$ ) using a subirrigated propagation system with nutrient circulation for hydroponic crop production (average temperature, $18.3{ }^{\circ} \mathrm{C}$ ). A diluted solution with an EC of 1.0 to $1.2 \mathrm{mS} \cdot \mathrm{cm}^{-1}$ and a $\mathrm{pH}$ of 5.8 was used as the first leaves appeared, per the recommendation on the fertilizer label. Lettuce seedlings were transplanted at 3 weeks from germination; the time from transplanting to harvest was 4 weeks. Supplemental lighting was used during crop production to achieve similar lighting conditions throughout the duration of the experiments. High-pressure sodium lamps were set up above the bench to provide $250 \pm 50 \mu \mathrm{mol} \cdot \mathrm{m}^{-2} \cdot \mathrm{s}^{-1}$ photosynthetically active radiation at plant height from 0600 to $1000 \mathrm{HR}$ in the morning. The daily light integral received during the experiments at bench height was $12.3 \pm$ $4.3 \mathrm{~mol} \cdot \mathrm{m}^{-2} \cdot \mathrm{d}^{-1}$. Lower and upper temperature set points in the greenhouse were 21.1 to $23.8{ }^{\circ} \mathrm{C}$ for both day and night. The average temperature for the duration of the experiments was $24 \pm 0.8{ }^{\circ} \mathrm{C}$, with a max- imum recorded temperature of $37.0{ }^{\circ} \mathrm{C}$. Average relative humidity was $72 \pm 2 \%$, with maximum relative humidity recorded at $96.5 \%$.

Expt. 1: Effect of EC on yield and tipburn. The NFT channel system (Crop King), consisted of 18 channels and eight separate solution tanks. The channels were connected randomly to the 75.7-L nutrient solution tanks. Each channel held 18 plants. 'Red Butter', 'Green Butter', and 'Red Oakleaf' were transplanted alternately (six plants of each cultivar per channel). Lettuce was grown at four different EC levels (1.4, 1.6, 1.8 , or $2.0 \pm 0.05 \mathrm{mS} \cdot \mathrm{cm}^{-1}$ ). EC levels were modified to the required level by adding nutrient stock solution to increase the EC and by adding water to decrease the EC. The border plants on the two outside channels were excluded from the data collection, resulting in 16 channels with four channels per treatment (each EC level), with each channel containing five to six plants from each cultivar. EC and $\mathrm{pH}$ levels in the stock tanks were monitored three times a week using EC (COM-100: Waterproof Professional Series EC/TDS Meter; HM Digital, Inc., Redondo Beach, CA) and pH (PH-200: Waterproof Professional Series $\mathrm{pH} / \mathrm{Temp}$ Meter, HM Digital, Inc.) meters. Solution $\mathrm{pH}$ was maintained at a constant of $5.8 \pm 0.05$ in all tanks using either phosphoric acid $(\mathrm{pH}$ Down; General Hydroponics, Sebastopol, CA) or potassium hydroxide and potassium carbonate ( $\mathrm{pH}$ Up, General Hydroponics). The average preadjusted $\mathrm{pH}$ was $5.86 \pm$ 0.02 for all stock tanks.

Expt. 2: Effect of $p H$ on yield and tipburn. 'Green Butter', 'Red Butter', and 'Red Oakleaf' were grown at different $\mathrm{pH}$ levels $(5.8,6,6.2$, or $6.4 \pm 0.05)$ in the NFT system as described in Expt. 1 (six plants of each cultivar and three cultivars per channel). Corresponding average $\mathrm{pH}$ levels before each adjustment were $5.90 \pm 0.02,6.04 \pm 0.02$, $6.26 \pm 0.01$, and $6.43 \pm 0.03$. Solution EC was maintained at a constant EC of $1.8 \pm 0.05$ $\mathrm{mS} \cdot \mathrm{cm}^{-1}$ in all tanks. Other cultural practices during the experiment were as described in Expt. 1.

Expt. 3: Effect of foliar application of $\mathrm{CaCl}_{2}$ on yield and tipburn. Lettuce cultivar Green Butter, susceptible to tipburn, was grown in four NFT systems with individual solution tanks. Each system consisted of six channels and each channel held nine plants. The border plants of each NFT system were excluded from data collection and analysis. A constant EC of $1.8 \pm 0.05 \mathrm{mS} \cdot \mathrm{cm}^{-1}$ and $\mathrm{pH}$ of $5.8 \pm 0.05$ were maintained in all solution tanks. $\mathrm{CaCl}_{2}$ (anhydrous 96\%; Thermo Fisher Scientific, Waltham, MA) solutions were prepared to provide $\mathrm{Ca}$ at $0,200,400$, or $800 \mathrm{mg} \cdot \mathrm{L}^{-1}$ after being dissolved in reverse-osmosis water. All treatments were applied twice a week as a foliar spray between 0800 and $1100 \mathrm{HR}$, starting a week after transplanting. Spray volume per plant during the crop growth ranged from $\approx 2 \mathrm{~mL}$ after transplanting to $\approx 15 \mathrm{~mL}$ 
Table 1. Analysis of variance for shoot fresh weight, shoot dry weight, root dry weight, and tipburn rating at harvest for Lactuca sativa ('Green Butter', 'Oak Leaf', and 'Red Butter') grown under four different electrical conductivity (EC) levels (Expt. 1: EC at 1.4, 1.6, 1.8, or $2.0 \mathrm{mS} \cdot \mathrm{cm}^{-1}$ ) at a constant pH of 5.8 and four different $\mathrm{pH}$ levels (Expt. 2: $\mathrm{pH}$ at $5.8,6,6.2$, or 6.4 ) at a constant EC of $1.8 \mathrm{mS} \cdot \mathrm{cm}^{-1}$.

\begin{tabular}{|c|c|c|c|c|c|}
\hline \multirow{2}{*}{\multicolumn{2}{|c|}{ Treatment }} & \multicolumn{4}{|c|}{ Parameter } \\
\hline & & Shoot fresh wt & Shoot dry wt & Root dry wt & Tipburn rating \\
\hline \multirow{3}{*}{ Expt. 2} & Cultivar & $* * *$ & $* * *$ & $* * *$ & $* * *$ \\
\hline & Cultivar & $* * *$ & $* * *$ & ** & $* * *$ \\
\hline & $\mathrm{pH} \times$ cultivar & NS & NS & NS & NS \\
\hline
\end{tabular}

Ns, ${ }^{*}, * *, * * *$ Nonsignificant or significant at $P \leq 0.05,0.01$, or 0.001 , respectively.

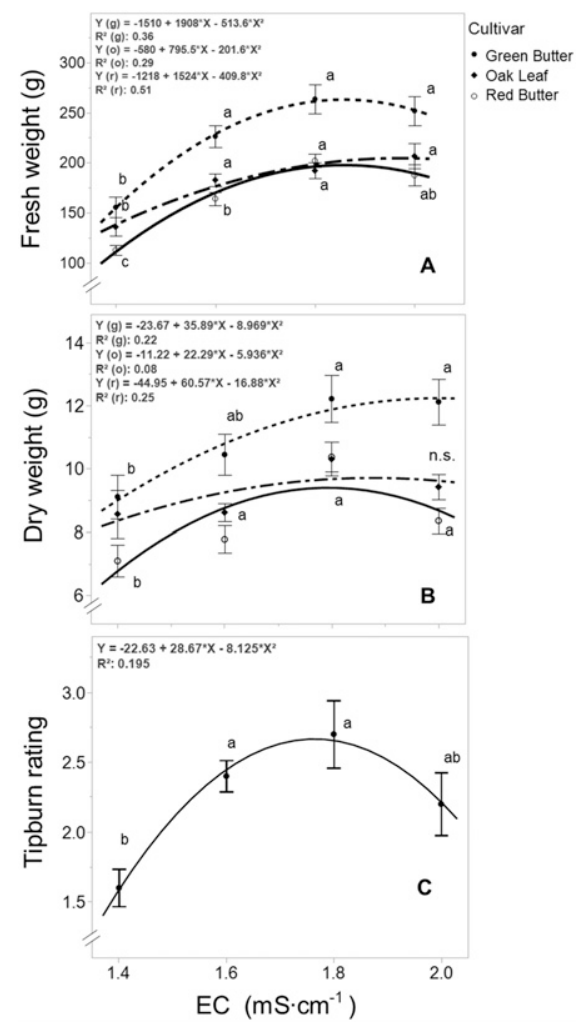

Fig. 1. (A) Fresh weight and (B) dry weight of the shoots of three cultivars of Lactuca sativa ('Green Butter', 'Oak Leaf', and 'Red Butter'), and $(\mathbf{C})$ tipburn rating measured at harvest on 'Green Butter', grown under four different electrical conductivity (EC) levels $(1.4,1.6$, 1.8 , or $\left.2.0 \mathrm{mS} \cdot \mathrm{cm}^{-1}\right)$ at a constant $\mathrm{pH}$ of 5.8 (Expt. 1). Vertical bars represent SE $(\mathrm{n}=22$ 24). Mean separation by Tukey's honestly significant difference test at $P \leq 0.05$.

before harvest, based on increasing canopy size and interception. The experiment was repeated once.

Yield and dry weight. Harvesting started 4 weeks after transplanting for all experiments. For Expts. 1 and 2, data were collected from plants excluding two border channels (four channels per treatment) and boundary plants in the center channels. For Expt. 3, data were collected from plants other than those on the two border channels on each side and the boundary plants in the center channels. Whole lettuce heads were harvested, and fresh weight per head and fresh root weight were determined at harvest. Shoots and roots were air-dried for $48 \mathrm{~h}$ and then placed in an oven at $60^{\circ} \mathrm{C}$ until the weight was constant before measuring shoot and root dry weights.

Tissue analysis. For Expts. 1 and 2, the top half of the lettuce plant, consisting of leaves and stem of 'Green Butter' lettuce was used for tissue analysis (six plants per treatment). Although regular tissue analysis is done using the most recent mature leaf (Campbell, 2000), for our research, focus was on tipburn, which is visible in younger leaves. To have more representative samples, therefore, the top half of the lettuce head-including actively growing leaf tissues - was used for analysis. Ovendried samples were ground in a mill (Tecator Cyclotec AB, Hogenas, Sweden) through a $0.5-\mathrm{mm}$ screen. Analysis of macro- and micronutrients of leaves was done using inductively coupled plasma optical emission spectrometry (iCAP 6300; Thermo Scientific, Schaumburg, IL) and a $\mathrm{CN}$ analyzer (Vario MICRO cube CHNS; Elementar, Mt. Laurel, NJ) at the U.S. Department of AgricultureAgriculture Research Service laboratory in Toledo, $\mathrm{OH}$. Results of tissue analyses were used to investigate the variations in nutrient uptake at different $\mathrm{EC}$ and $\mathrm{pH}$ levels.

Tipburn evaluation. A scale 0 to 4 was developed for the evaluation of tipburn symptoms based on those leaves that are visible on the top of the head and in the center closer to the apical meristem (average, 30 leaves/plant): $0=$ no symptoms; $1=$ few patches in the margins of some leaves; $2=$ patches on the margins of more than $50 \%$ of the leaves; 3 = continuous necrotic patches on the margins of some leaves; and $4=$ continuous necrotic patches on the margins of more than $50 \%$ of the leaves.

Data analysis. Data were subjected to analyses of variance using JMP Pro 10 (SAS Institute, Cary, NC). Expts. 1 and 2 were arranged as a completely randomized design with a factorial arrangement of treatments. Fresh weight, dry weight, and tipburn were analyzed with $\mathrm{EC}$ or $\mathrm{pH}$ levels, and lettuce cultivar as main effects. Macro- and micronutrients were analyzed with $\mathrm{EC}$ or $\mathrm{pH}$ levels as the independent variable using the tissue analysis of cultivar Green Butter. Regression analyses were performed to interpret the relationship between $\mathrm{EC}$ or $\mathrm{pH}$ and the parameters measured. For the tipburn evalu- ation, only data from 'Green Butter' were presented because it is the most susceptible cultivar and provided a better evaluation of symptoms because of the color contrast. Expt. 3 was arranged as a completely randomized design. For Expt. 3, analyses of variance were performed with the concentration of $\mathrm{Ca}$ as the independent variable and fresh weight, dry weight, and tipburn as dependent variables. Regression plots are presented in the figures to display the significant responses to $\mathrm{CaCl}_{2}$ sprays. Pairwise comparison of means was conducted using Tukey's honestly significant difference test at $P \leq 0.05$.

\section{Results}

Effect of EC. During Expt. 1 with varying EC levels, cultivar differences in fresh weight were evident $(P<0.001)$; however, there were no interactions between cultivars and EC (Table 1). The maximum fresh weights were in treatments at or more than 1.8 $\mathrm{mS} \cdot \mathrm{cm}^{-1}$ for 'Green Butter' $(263 \pm 14 \mathrm{~g} /$ head) and 'Red Butter' (202 $\pm 8 \mathrm{~g})$, and at or more than $1.6 \mathrm{mS} \cdot \mathrm{cm}^{-1}$ for 'Red Oakleaf' $(183 \pm 6 \mathrm{~g})$. Fresh weight remained the same in treatments between 1.8 and $2.0 \mathrm{mS} \cdot \mathrm{cm}^{-1}$ for all cultivars, and therefore increasing EC beyond $1.8 \mathrm{mS} \cdot \mathrm{cm}^{-1}$ did not contribute to increasing yields $(P<0.001$; Fig. 1A). Shoot dry weight was greater at or more than 1.8 $\mathrm{mS} \cdot \mathrm{cm}^{-1}$ for 'Green Butter' and 'Red Butter', and remained similar across EC treatments for 'Red Oakleaf' $(P<0.001$; Fig. 1B). Root dry weight reduced slightly with increasing EC $(P<0.001)$ in all cultivars (data not shown). The greatest root weight was in 'Green Butter' $(1.73 \pm 0.27 \mathrm{~g})$, followed by 'Red Butter' (1.57 $\pm 0.33 \mathrm{~g})$ and 'Red Oakleaf' $(1.48 \pm 0.30 \mathrm{~g})$.

Tipburn symptoms were visible in 'Green Butter' whereas other cultivars were not highly susceptible (Table 1); therefore, only data for 'Green Butter' are presented (Fig. 1C). Tipburn was at a minimum at 1.4 $\mathrm{mS} \cdot \mathrm{cm}^{-1}$, with a rating of 1.2 . The yield of 'Green Butter', however, was $75 \mathrm{~g}$ less at 1.4 $\mathrm{mS} \cdot \mathrm{cm}^{-1}$ compared with $1.8 \mathrm{mS} \cdot \mathrm{cm}^{-1}$, which had a tipburn rating of 2.7. Dry weight was 2 $\mathrm{g}$ less at $1.4 \mathrm{mS} \cdot \mathrm{cm}^{-1}$ compared with 1.8 $\mathrm{mS} \cdot \mathrm{cm}^{-1}$.

Based on the tissue nutrient analysis of 'Green Butter', macronutrients N $(P<0.001)$ and $\mathrm{P}(P<0.001)$ reached the maximum uptake at or near $1.8 \mathrm{mS} \cdot \mathrm{cm}^{-1}$ (Fig. 2). 


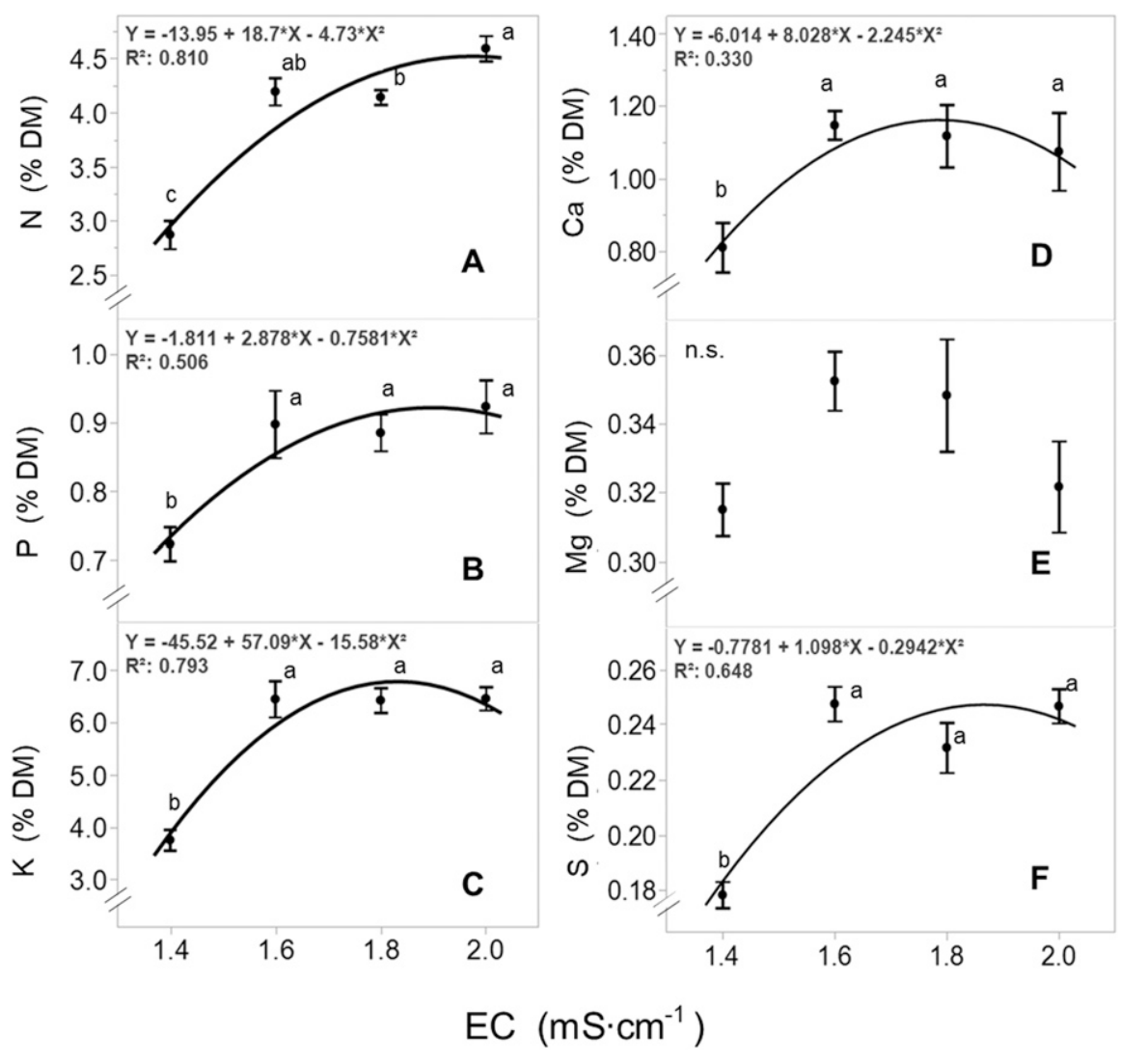

Fig. 2. Concentration of (A) nitrogen $(\mathrm{N}),(\mathbf{B})$ phosphorus $(\mathrm{P}),(\mathbf{C})$ potassium $(\mathrm{K}),(\mathbf{D})$ calcium $(\mathrm{Ca}),(\mathbf{E})$ magnesium $(\mathrm{Mg})$, and $(\mathbf{F})$ sulfur $(\mathrm{S})$ as a percentage of dry matter $(\mathrm{DM})$ in leaves of the top half of the Lactuca sativa 'Green Butter' head grown under four different electrical conductivity (EC) levels (1.4, $1.6,1.8$, or $\left.2.0 \mathrm{mS} \cdot \mathrm{cm}^{-1}\right)$ at a constant $\mathrm{pH}$ of 5.8 (Expt. 1). Vertical bars represent SE $(\mathrm{n}=6)$. Mean separation by Tukey's honestly significant difference test at $P \leq 0.05$. n.s., nonsignificant.

Potassium $(P<0.001), \mathrm{Ca}(P<0.05)$, and $\mathrm{S}$ $(P<0.001)$ concentrations increased up to $1.6 \mathrm{mS} \cdot \mathrm{cm}^{-1}$, but remained the same thereafter with the increasing EC. Concentrations of $\mathrm{P}, \mathrm{K}$, and $\mathrm{S}$ remained the same at $2.0 \mathrm{mS} \cdot \mathrm{cm}^{-1}$ compared with $1.8 \mathrm{mS} \cdot \mathrm{cm}^{-1}$, although the nutrient levels increased in the solution. Nitrogen concentration, however, increased with increasing EC $(P<0.001)$. Magnesium concentration was similar across EC treatments $(P>0$. 05). Based on a sufficiency range of nutrients for greenhouse lettuce (Campbell, 2000), N was sufficient at and more than $1.8 \mathrm{mS} \cdot \mathrm{cm}^{-1}$. Phosphorus was sufficient at all EC ranges. Potassium, Ca, and $\mathrm{S}$ were sufficient at greater than 1.6 $\mathrm{mS} \cdot \mathrm{cm}^{-1}$. Magnesium reached the lower end of the sufficiency range near $2.0 \mathrm{mS} \cdot \mathrm{cm}^{-1}$. Micronutrients $\mathrm{Mn}(P<0.02)$, Mo $(P<$ $0.001)$, and $\mathrm{Zn}(P<0.001)$ changed in a similar pattern to some of the macronutrients, where uptake increased and was at a similar concentration beyond $1.6 \mathrm{mS} \cdot \mathrm{cm}^{-1}$ (Fig. 3). There was no influence on $\mathrm{B}$ as a result of changing EC levels. In contrast, $\mathrm{Cu}(P<$ $0.001)$ and $\mathrm{Fe}(P<0.001)$ concentration increased with increasing EC. All micronutrients were within the sufficiency range for lettuce (Campbell, 2000).

Effect of $p H$. During Expt. 2 with varying $\mathrm{pH}$ levels, yield was affected by cultivar $(P<$ $0.001)$ but not $\mathrm{pH}$ or its interaction with cultivar (Table 1). 'Green Butter' had the greatest fresh weight $(320 \pm 9 \mathrm{~g})$, followed by 'Red Oakleaf' (268 $\pm 6 \mathrm{~g}$ ) and 'Red Butter' $(234 \pm 9 \mathrm{~g})$. Compared with the recommended $\mathrm{pH}$ of 5.8 , the increase in fresh weight at higher $\mathrm{pH}$ levels was minimal, with $47 \mathrm{~g}$ for 'Green Butter', $28 \mathrm{~g}$ for 'Red Oakleaf', and $22 \mathrm{~g}$ for 'Red Butter' (Fig. 4A). Yield at $\mathrm{pH} 6.4$ was less than $\mathrm{pH}$ 5.8 for 'Red Oakleaf' and 'Red Butter'. Shoot dry weight varied with cultivars in pattern similar to fresh weight $(P<0.001$; Fig. 4B); however, the response to $\mathrm{pH}$ was not significant (Table 1). Root dry weight also varied based on the cultivar $(P<0.01)$ - 'Green Butter' (3.70 \pm 0.04 g), 'Red Butter' (3.52 \pm $0.04 \mathrm{~g})$, and 'Red Oakleaf' $(3.48 \pm 0.04 \mathrm{~g})$ but not because of the $\mathrm{pH}$ changes (data not shown).

There was no variation in tipburn symptoms for 'Green Butter' across pH levels, with an average tipburn rating of 1.6 (Table 1). For 'Red Oakleaf' and 'Red Butter', tipburn symptoms were marginal compared with 'Green Butter', and therefore data for 'Green Butter' only are presented (Fig. 4C).

Based on tissue nutrient analysis of 'Green Butter' lettuce, N and S concentrations increased with increasing $\mathrm{pH}$ up to 6.0 and reduce after 6.2 , indicating $\mathrm{N}(P<$ $0.0001)$ and $\mathrm{S}(P<0.001)$ uptake patterns change significantly across these ranges, with the lowest at 6.4 (Fig. 5). Phosphorus uptake levels remained similar from 5.8 to 6.2 and decreased at $6.4(P<0.01)$. Leaf tissue concentration of $\mathrm{K}(P<0.001)$ and $\mathrm{Ca}(P<$ $0.001)$ reduced linearly with increasing $\mathrm{pH}$. Magnesium uptake was not different among treatments $(P>0.05)$. Nitrogen was within the sufficiency range (Campbell, 2000) except at $\mathrm{pH}$ 6.4. Phosphorus, $\mathrm{K}, \mathrm{Mg}$, and $\mathrm{S}$ were sufficient at all $\mathrm{pH}$ treatments. Calcium, however, was deficient at a $\mathrm{pH}$ of more than 6.2. B did not vary with changing $\mathrm{pH}$ levels within the range of 5.8 to $6.4(P>0.05)$. $\operatorname{Iron}(P<0.0001), \operatorname{Mn}(P<0.0001), \mathrm{Zn}(P<$ $0.0001)$, and Mo $(P<0.001)$ uptake decreased gradually with increasing $\mathrm{pH}$ (Fig. 6). Copper levels increased and reached the maximum at a $\mathrm{pH}$ of 6.0 , then decreased gradually thereafter $(P<0.001)$. All micronutrients remained within their sufficiency range at all $\mathrm{pH}$ levels; however, they reached the lower limit of their sufficiency range at pH 6.4 (Campbell, 2000). Boron remained at the lower end of the sufficiency range at all $\mathrm{pH}$ levels.

Effect of foliar application of $\mathrm{CaCl}_{2}$. Fresh weight decreased with the increased application rate of $\mathrm{CaCl}_{2}(P<0.001$; Fig. 7A) Fresh weight was 25 g less at 800 $\mathrm{mg} \cdot \mathrm{L}^{-1}$ than at 0 and $200 \mathrm{mg} \cdot \mathrm{L}^{-1} \mathrm{CaCl}_{2}$. Dry weight also reduced with the increased concentration of $\mathrm{CaCl}_{2}$ at $800 \mathrm{mg} \cdot \mathrm{L}^{-1}$, and was $2 \mathrm{~g}$ less than at 0 and $200 \mathrm{mg} \cdot \mathrm{L}^{-1}(P<0.0001$; Fig. 7B). At $400 \mathrm{mg} \cdot \mathrm{L}^{-1} \mathrm{CaCl}_{2}$, the fresh weight reduction was $30 \mathrm{~g}$ and the dry weight reduction was $1 \mathrm{~g}$ compared with the control. Applications twice per week of 400 and 800 $\mathrm{mg} \cdot \mathrm{L}^{-1} \mathrm{Ca}$, however, reduced tipburn compared with other treatments $(P<0.0001$; Fig. 7C). Tipburn rating was reduced from 2.5 to 0.75 with the increased application of $\mathrm{CaCl}_{2}$. No phytotoxicity symptoms were observed from $\mathrm{CaCl}_{2}$ application (data not shown).

\section{Discussion}

Production of lettuce at the recommended EC produced the greatest yield but not the highest quality, because tipburn symptoms were greater in some cultivars. The greatest yield was at an EC of $1.8 \mathrm{mS} \cdot \mathrm{cm}^{-1}$ compared with 1.4 and $2.2 \mathrm{mS} \cdot \mathrm{cm}^{-1}$, and that was previously recorded for lettuce production in fall and winter (Samarakoon et al., 2019). Our study confirms that growing at 1.8 $\mathrm{mS} \cdot \mathrm{cm}^{-1}$ in summer is better than 1.6 and $2.0 \mathrm{mS} \cdot \mathrm{cm}^{-1}$ in terms of yield. In addition, growing at $2.0 \mathrm{mS} \cdot \mathrm{cm}^{-1}$ did not contribute to additional uptake of most of the essential elements. Therefore, nutrients remain in the solution, leading to fertilizer waste if the nutrient solution is not reused. Reducing EC level to less than the recommended levels did not increase yield in lettuce in the summer growing conditions in our study, although it this has been reported for other types of hydroponic systems (Abou-Hadid et al., 1995; Samarakoon et al., 2006; Serio et al., 2000). The differences between hydroponic 


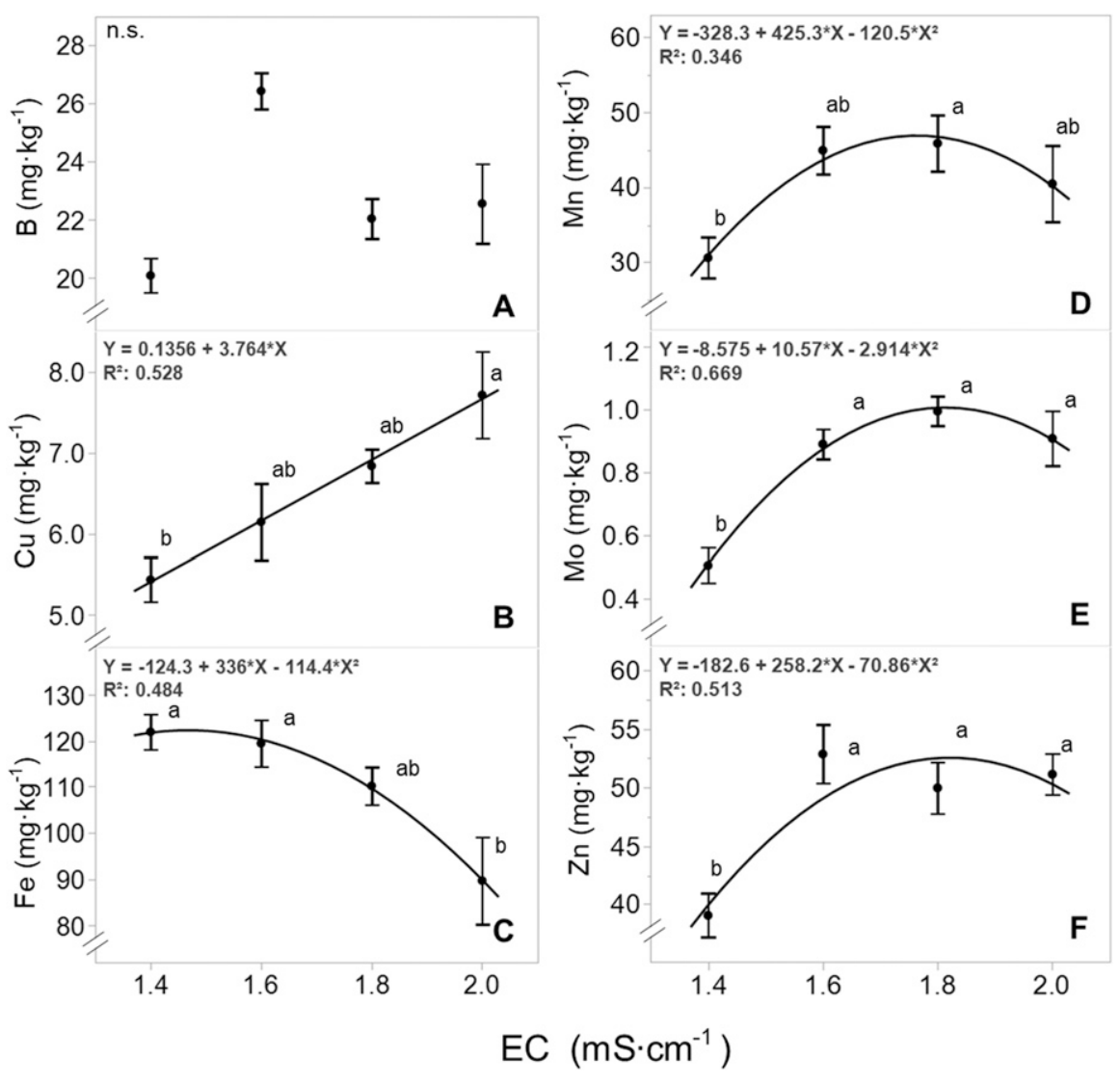

Fig. 3. (A) Concentration of boron (B), (B) copper (Cu), (C) iron (Fe), (D) manganese $(\mathrm{Mn}),(\mathbf{E})$ molybdenum (Mo), and (F) zinc ( $\mathrm{Zn}$ ) in leaves of top half of the Lactuca sativa 'Green Butter' head grown under four different electrical conductivity (EC) levels $\left(1.4,1.6,1.8\right.$, or $\left.2.0 \mathrm{mS} \cdot \mathrm{cm}^{-1}\right)$ at a constant $\mathrm{pH}$ of 5.8 (Expt. 1). Vertical bars represent SE $(\mathrm{n}=6)$. Mean separation by Tukey's honestly significant difference test at $P \leq 0.05$. n.s., nonsignificant.

systems in response to EC optimization requires further investigation because the volume of nutrient solution in contact with the root systems affects water and nutrient uptake directly.

Macronutrients $\mathrm{N}, \mathrm{K}, \mathrm{Ca}$, and $\mathrm{S}$ were less than the sufficiency range at EC levels less than $1.6 \mathrm{mS} \cdot \mathrm{cm}^{-1}$. Reduced macronutrients have contributed to reduced growth at EC levels, as reported previously in hydroponics lettuce (Fallovo et al., 2009; Samarakoon et al., 2019). In herbs (Ocimum spp., Coriandrum sativum, Anethum graveolens, and Petroselinum crispum) grown in NFT systems, yield was not influenced by EC changes between 0.5 to $4.0 \mathrm{mS} \cdot \mathrm{cm}^{-1}$ (Currey et al., 2019; Walters and Currey, 2018). In those studies, EC adjustments were done every day or automatically, and the tank size for the nutrient solution was double compared with our study. Under such condition, nutrients may be sufficiently available even at low EC levels. Therefore, yield response to EC adjustment may also vary with the plant species, frequency of EC adjustment, and tank size in hydroponics.

To reduce tipburn symptoms in susceptible cultivars, growers may need to use a lower EC of $1.4 \mathrm{mS} \cdot \mathrm{cm}^{-1}$, where tipburn symptoms were minimum. At an EC of 1.4 $\mathrm{mS} \cdot \mathrm{cm}^{-1}$, some macronutrients became defi- cient; however, micronutrients were in sufficient quantities. As evident by fresh weight, lower growth rates associated with low EC levels reduce the need for high levels of $\mathrm{Ca}$ and therefore alleviate tipburn. Calcium concentration in the leaf tissue did not increase after $1.6 \mathrm{mS} \cdot \mathrm{cm}^{-1}$, although the levels increased in the nutrient solution, indicating $\mathrm{Ca}$ growth at high EC levels. Thus, the faster growth rates at high EC levels demanded more $\mathrm{Ca}$ and led to inadequate $\mathrm{Ca}$ in leaf tissues and subsequent development of tipburn.

Addition of $\mathrm{Ca}$ to the nutrient solution, therefore, may not to be helpful and could lead to a further increase of EC in the solution. Although there is a reduction of $75 \mathrm{~g}$ fresh head weight at $1.4 \mathrm{mS} \cdot \mathrm{cm}^{-1}$, hydroponic lettuce is sold in many ways. When sold in clear plastic containers, a head size that fills the container is important compared with the weight. The Salanova ${ }^{\circledR}$ cultivars consist of many small leaves and, therefore, most are used in formulating salad mixes. Although the salad mixes are sold by weight, multiple plant species or cultivars can be added to formulate the mix. Therefore, if growers can identify such strategies, a reduced weight will likely not influence sales. Therefore, in terms of cultivars susceptible to tipburn, growing at is not taken up to support increased plant

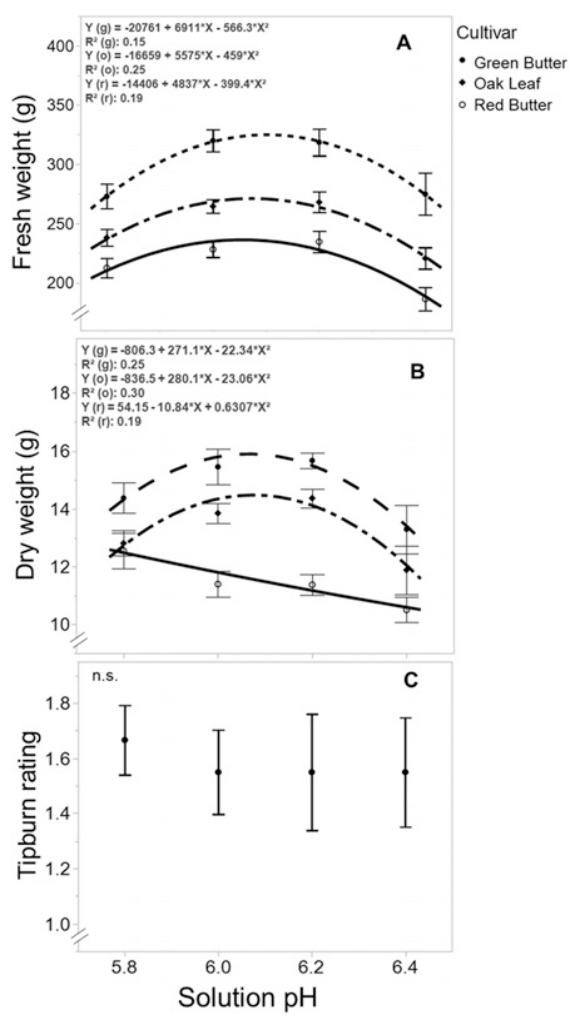

Fig. 4. (A) Fresh weight and (B) dry weight of the shoots of three cultivars of Lactuca sativa ('Green Butter', 'Oak Leaf', and 'Red Butter'), and (C) tipburn rating measured at harvest on 'Green Butter', grown under four different $\mathrm{pH}$ levels $(5.8,6,6.2$, or 6.4$)$ at a constant electrical conductivity of $1.8 \mathrm{mS} \cdot \mathrm{cm}^{-1}$ (Expt. 2). Vertical bars represent SE $(\mathrm{n}=22-24)$. Mean separation by Tukey's honestly significant difference test at $P \leq 0.05$. n.s., nonsignificant.

a low EC $\left(1.4 \mathrm{mS} \cdot \mathrm{cm}^{-1}\right)$ will benefit in producing a marketable product compared with unsaleable products grown at a high EC (1.8 $\mathrm{mS} \cdot \mathrm{cm}^{-1}$ ).

The yield variations were considerably less under different $\mathrm{pH}$ levels. Therefore, significant growth changes did not occur among the $\mathrm{pH}$ levels tested based on shoot or root dry weight. The yield was greater at $\mathrm{pH} 6.0$, which was slightly greater than the recommendation of $\mathrm{pH} 5.8$. Based on the nutrient uptake pattern, tissue $\mathrm{N}$ was greater at $\mathrm{pH} 6.0$, which may have caused the increased yield; however, there was no difference in uptake of other macro- or micronutrients between $\mathrm{pH} 5.8$ and 6.0. Changing $\mathrm{pH}$ levels from the recommended level did not reduce the tipburn symptoms because all treatments displayed similar tipburn ratings. Adjusting $\mathrm{pH}$, therefore, cannot be used as a strategy to control tipburn in lettuce.

Based on our results, yield can be comparable across a pH range of 5.8 to 6.2 ; however, significant reductions can occur at a $\mathrm{pH}$ greater than 6.4 , with many macro- and micronutrients becoming deficient. At a high $\mathrm{pH}$, some of the micronutrients lose solubility and therefore are not available for uptake in the solution (Tyson et al., 2008). Growing at a high $\mathrm{pH}$ can happen when growers use 


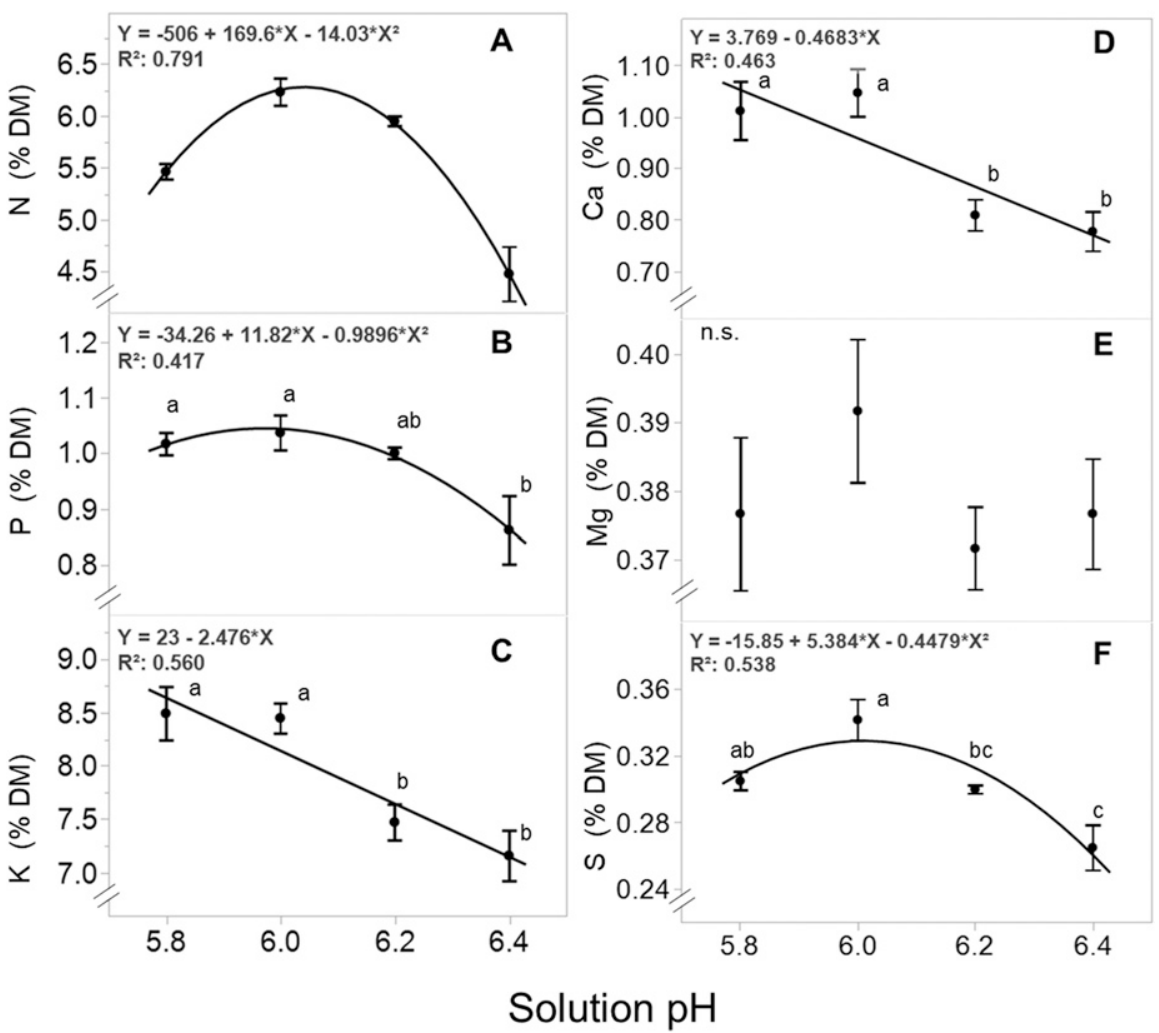

Fig. 5. (A) Concentration of nitrogen (N), (B) phosphorus (P), (C) potassium (K), (D) calcium (Ca), (E) magnesium (Mg), and (F) sulfur (S) as a percentage of dry matter (DM) in leaves of top half of the head of Lactuca sativa 'Green Butter' at four different pH levels $(5.8,6,6.2$, or 6.4) at constant electrical conductivity of $1.8 \mathrm{mS} \cdot \mathrm{cm}^{-1}$ (Expt. 2). Vertical bars represent SE $(\mathrm{n}=6)$. Mean separation by Tukey's honestly significant difference test at $P \leq 0.05$. n.s., nonsignificant.

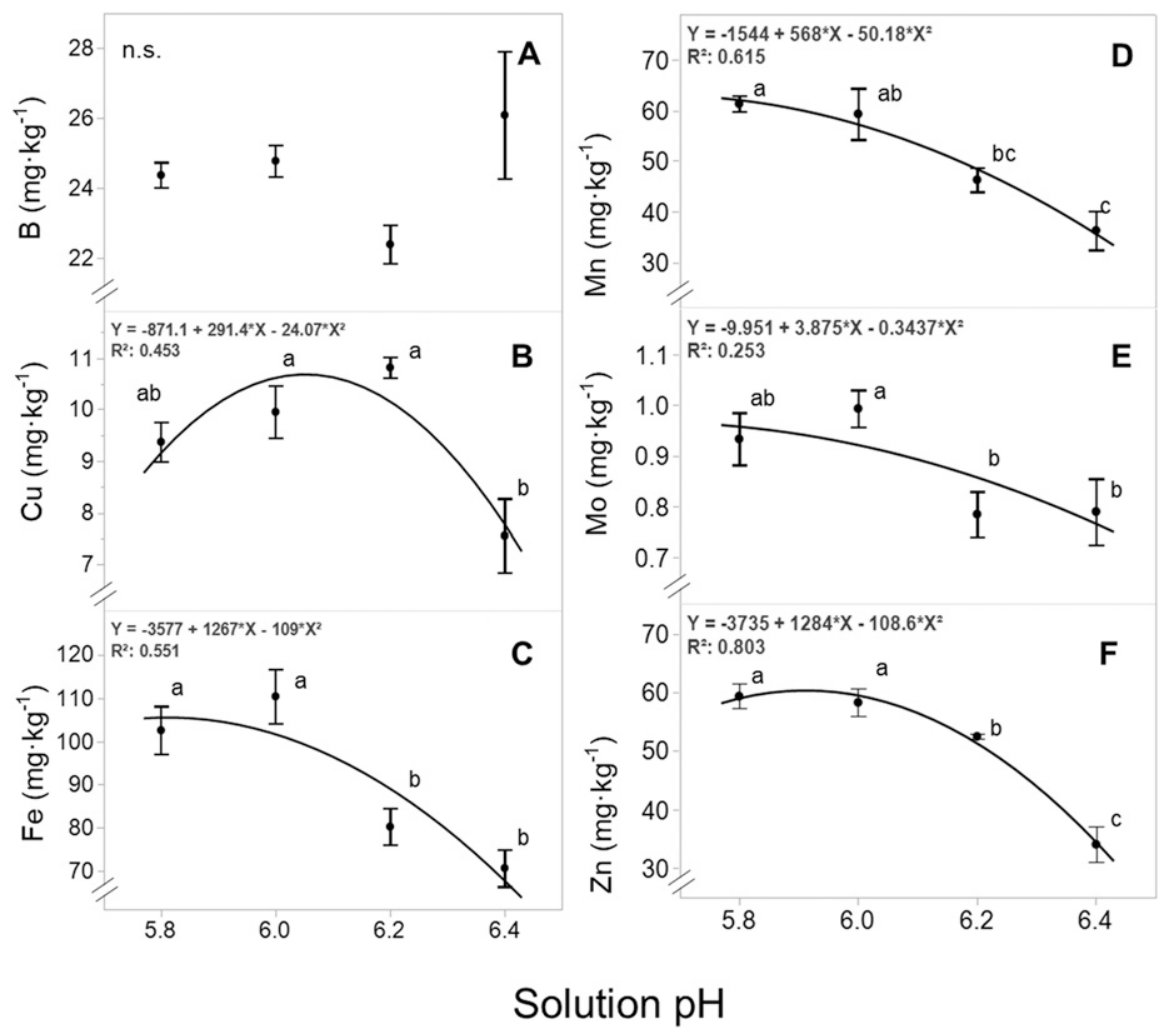

Fig. 6. (A) Concentration of boron (B), (B) copper (Cu), (C) iron (Fe), (D) manganese (Mn), (E) molybdenum (Mo), and (F) zinc ( $\mathrm{Zn}$ ) in leaves of the top half of the head of Lactuca sativa 'Green Butter' at four different $\mathrm{pH}$ levels $(5.8,6,6.2$, or 6.4$)$ at constant electrical conductivity of $1.8 \mathrm{mS} \cdot \mathrm{cm}^{-1}$ (Expt. 2). Vertical bars represent SE $(\mathrm{n}=6)$. Mean separation by Tukey's honestly significant difference test at $P \leq 0.05$. alkaline water that acts as a buffer that resists pH change. Growers who adjust EC manually also encounter high $\mathrm{pH}$ levels between adjustments. As evident in our study, yield variations are marginal across $\mathrm{pH} 5.8$ to 6.2. Therefore, our study also provides some guidance to growers who experience high $\mathrm{pH}$ levels resulting from the initial water quality.

Application of $\mathrm{CaCl}_{2}$ controlled tipburn effectively at the recommended $\mathrm{pH}$ of 5.8 and the EC of $1.8 \mathrm{mS} \cdot \mathrm{cm}^{-1}$. Growers can apply $\mathrm{CaCl}_{2}$ as a routine application, twice a week after transplanting, because a one-time application was not sufficient. Application of $\mathrm{Ca}$ directly to shoots can increase Ca deposition in leaves, as noted by increased $\mathrm{Ca}$ in leaf tissues. Therefore, $\mathrm{Ca}$ is readily available to young leaf tissues without the reliance on transportation from older leaf leaves and roots (White and Broadley, 2003). As a result, even if environmental conditions such as transpiration rates are not optimal for $\mathrm{Ca}$ mobilization from the root during the summer, $\mathrm{Ca}$ can be taken up readily by the leaves directly to alleviate tipburn. The yield reduction after application of $\mathrm{CaCl}_{2}$ was minimal compared with reducing the EC to 1.4 $\mathrm{mS} \cdot \mathrm{cm}^{-1}$ to control tipburn. Yield reduction at a high $\mathrm{CaCl}_{2}$ level has not been reported for lettuce; however, reduced shoot dry weight was reported for Nardus stricta L. and Sieglingia decumbens L., with increased $\mathrm{CaCl}_{2}$ concentration in the root zone (White and Broadley, 2003). Further investigations are underway to understand the growth response to foliar applications of $\mathrm{CaCl}_{2}$.

Foliar $\mathrm{Ca}$ application was found to increase the mechanical strength of the leaves and therefore was beneficial in reducing postharvest loses (Li et al., 2012; Samarakoon et al., 2017). In addition, $\mathrm{CaCl}_{2}$ was found to be effective in controlling fungal diseases (Bennett et al., 2020; Samarakoon et al., 2016; Starkey and Pedersen, 1997). Therefore, it is possible that growers may get additional benefits related to disease control, and further investigations are underway to confirm them. Based on our study, 400 to 800 $\mathrm{mg} \cdot \mathrm{L}^{-1} \mathrm{Ca}$ in the form $\mathrm{CaCl}_{2}$ is recommended for 'Green Butter' lettuce. The morphology of the cultivar in our study, was a leafy lettuce cultivar that allows young leaf tissues to receive the spray solution effectively. However, other cultivars with different morphologies, such as enclosed leaves, may respond to $\mathrm{Ca}$ foliar applications differently.

\section{Conclusion}

Our investigation provides guidelines for optimum EC and $\mathrm{pH}$ management for NFT lettuce under summer growing conditions. Our investigation also provides evidence for two potential nutrient management strategies to control tipburn. One is reducing the $\mathrm{EC}$ of the nutrient solution to less than $1.4 \mathrm{mS} \cdot \mathrm{cm}^{-1}$ and the other is a twice-a-week application of $\mathrm{CaCl}_{2}$ at rates of 400 or $800 \mathrm{mg} \cdot \mathrm{L}^{-1} \mathrm{Ca}$. Of the two techniques, application of $\mathrm{CaCl}_{2}$ provided a better control as the symptom of 


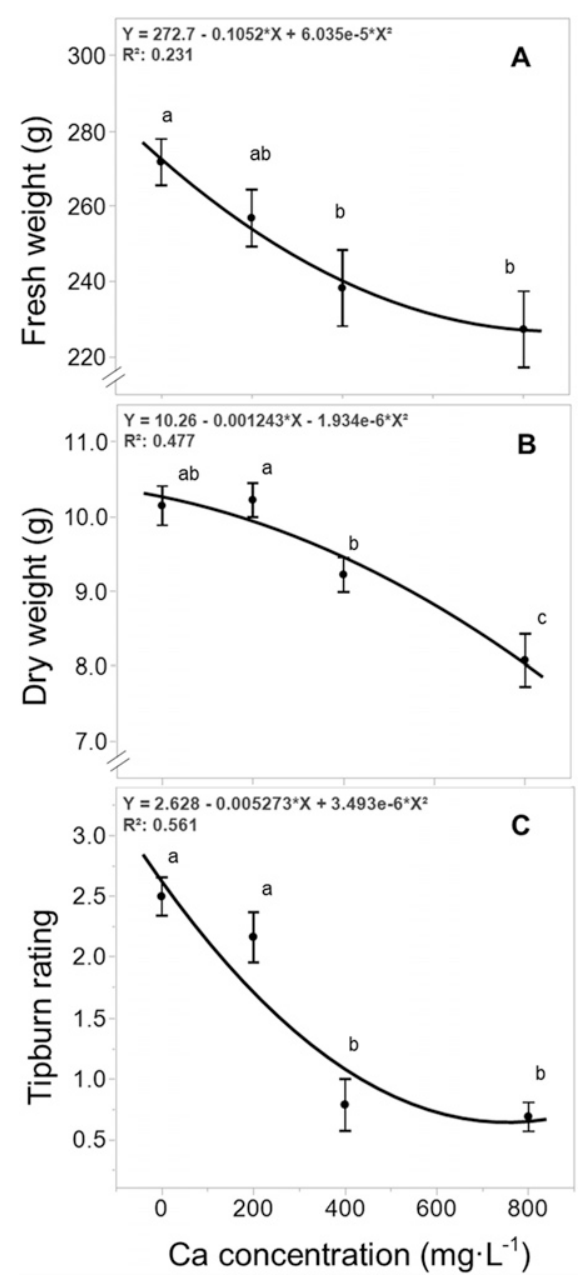

Fig. 7. (A) Fresh weight, (B) dry weight, (C) and tipburn rating of Lactuca sativa 'Green Butter' at harvest after twice-a-week foliar spray applications of calcium chloride $\left(\mathrm{CaCl}_{2}\right)$ to provide calcium (Ca) at $0,200,400$, or $800 \mathrm{mg} \cdot \mathrm{L}^{-1}$, and at a constant electrical conductivity and $\mathrm{pH}$ of 1.8 $\mathrm{mS} \cdot \mathrm{cm}^{-1}$ and 5.8, respectively. Vertical bars represent SE $(\mathrm{n}=16)$. Mean separation by Tukey's honestly significant difference test at $P \leq 0.05$.

tipburn was minimal and the impact on yield was minor compared with reducing the EC. Growers can choose an appropriate strategy based on the convenience of integration into existing management practices.

\section{Literature Cited}

Abou-Hadid, A.F., E.M. Abd-Elmoniem, M.Z. ElShinawy, and M. Abou-Elsoud. 1995. Electrical conductivity effect on growth and mineral composition of lettuce plants in hydroponic system. Acta Hort. 434:59-66.

Barta, D.J. and T.W. Tibbitts. 2000. Calcium localization and tipburn development in lettuce leaves during early enlargement. J. Amer. Soc. Hort. Sci. 125:294-298.

Bennett, K., J. Jent, U. C. Samarakoon, G. Schnabel, and J. E. Faust. 2020. Reduction of Botrytis cinerea infection on petunia flowers following calcium spray applications. HortScience 55:188-191.

Brechner, M., A.J. Both, and C.E.A. Staff. 2013 Hydroponic lettuce handbook. Cornell Controlled Environment Agriculture, Ithaca, NY.

Campbell, C. 2000. Reference sufficiency ranges for plant analysis in the southern region of the United States. Southern Reg. Agr. Expt. Sta., Raleigh, NC.

Cox, E.F., J.M.T. McKee, and A.S. Dearman. 1976. The effect of growth rate on tipburn occurrence in lettuce. J. Hort. Sci. 51(3):297309.

Currey, C.J., K.J. Walters, and N.J. Flax. 2019. Nutrient solution strength does not interact with the daily light integral to affect hydroponic cilantro, dill, and parsley growth and tissue mineral nutrient concentrations. Agronomy 9(7):389.

De Rijck, G. and E. Schrevens. 1999. Anionic speciation in nutrient solutions as a function of pH. J. Plant Nutr. 22(2):269-279.

Fallovo, C., Y. Rouphael, E. Rea, A. Battistelli, and G. Colla. 2009. Nutrient solution concentration and growing season affect yield and quality of Lactuca sativa $\mathrm{L}$. var. acephala in floating raft culture. J. Sci. Food Agr. 89(10):1682-1689.

Frantz, J.M., G. Ritchie, N.N. Cometti, J. Robinson, and B. Bugbee. 2004. Exploring the limits of crop productivity: Beyond the limits of tipburn in lettuce. J. Amer. Soc. Hort. Sci. 129:331-338.

Gilliham, M., M. Dayod, B.J. Hocking, B. Xu, S.J. Conn, B.N. Kaiser, R.A. Leigh, and S.D. Tyerman. 2011. Calcium delivery and storage in plant leaves: Exploring the link with water flow. J. Expt. Bot. 62(7):2233-2250.

Kuo, C.G., J.S. Tsay, C.L. Tsai, and R.J. Chen. 1981. Tipburn of chinese cabbage in relation to calcium nutrition and distribution. Scientia Hort. 14(2):131-138.

Li, C., J. Tao, D. Zhao, C. You, and J. Ge. 2012. Effect of calcium sprays on mechanical strength and cell wall fractions of herbaceous peony (Paeonia lactiflora Pall.) inflorescence stems. Intl. J. Mol. Sci. 13(4):4704-4713.

Samarakoon, U.C., K. Bennett, J. Jent, C. Chiu, G. Schnabel, and J. Faust. 2016. Alternative compounds to control gray mold. Grower Talks 79(10):52-54

Samarakoon, U.C., J.E. Faust, and J.M. Dole. 2017. Quantifying the effects of foliar-applied calcium chloride and its contribution to postharvest durability of unrooted cuttings. HortScience 52:1790-1795.

Samarakoon, U.C., C. Fyffe, J. Bale, P. Ling, S. Basnagala, N. Donley, and J. Altland. 2019. Effect of electrical conductivity on the productivity and nutrient uptake of Lactuca sativa $\mathrm{L}$. grown using nutrient film technique (NFT). Acta Hort. 1266:137-144.

Samarakoon, U.C., P.A. Weerasinghe, and W.A.P. Weerakkody. 2006. Effect of electrical conductivity (EC) of the nutrient solution on nutrient uptake, growth and yield of leaf lettuce (Lactuca sativa $\mathrm{L}$.) in stationary culture. Trop. Agr. Res 18:13-21.

Serio, F., A. Elia, P. Santamaria, and G.R. Rodriguez. 2000. Lettuce growth, yield and nitrate content as affected by electrical conductivity of nutrient solution. Acta Hort. 559:563-568.

Starkey, K.R. and A.R. Pedersen. 1997. Increased levels of calcium in the nutrient solution improves the postharvest life of potted roses. J. Amer. Soc. Hort. Sci. 122:863-868.

Tyson, R.V., E.H. Simonne, D.D. Treadwell, M. Davis, and J.M. White. 2008. Effect of water $\mathrm{pH}$ on yield and nutritional status of greenhouse cucumber grown in recirculating hydroponics. J. Plant Nutr. 31(11):20182030.

Walters, K.J., B.K. Behe, C.J. Currey, and R.G. Lopez. 2020. Historical, current, and future perspectives for controlled environment hydroponic food crop production in the United States. HortScience 55:758-767.

Walters, K.J. and C.J. Currey. 2018. Effects of nutrient solution concentration and daily light integral on growth and nutrient concentration of several basil species in hydroponic production. HortScience 53:1319-1325.

Watson, J.A., C. Gomez, R.A. Bucklin, R.W Henley, and D.B. McConnell. 2019. Fan and pad greenhouse evaporative cooling systems. Circular, Florida Coop. Ext. Serv.

Whipker, B.E., T.J. Cavins, and W.C. Fonteno. 2001. 1, 2, 3's of PourThru. North Carolina State Univ. Floriculture Res. $<$ http://www.ces.ncsu.edu/depts/hort/floriculture/Florex/PourThru>.

White, P.J. and M.R. Broadley. 2003. Calcium in plants. Ann. Bot. 92(4):487-511. 